\title{
広がる炭素膜の用途
}

\author{
中 東 孝 浩 \\ 日本アイ・ティ・エフ株式会社技術部＼cjkstart焉601-8205 京都府京都市南区久世殿城町 575 \\ （2003 年 11 月 27 日受理）
}

\section{Usage of Extending Carbon Films Including DLC}

Takahiro NAKAHIGASHI

Nippon ITF Inc.

575 Kuze Tonoshiro-cyo, Minami-ku, Kyoto 601-8205

(Received November 27, 2003)

\begin{abstract}
DLC (Diamond-Like Carbon), a kind of the hard carbon film, has such features as the lowest friction coefficient among various ceramic coating materials, high hardness, and less damage in the counterparts. Because of these features, many developments regarding the application for various kinds of sliding parts are in progress. However, people now call other films DLC, too, even though they are different from those defined in ' $80 \mathrm{~s}$. Moreover, new manufacturing methods such as sputtering and cathodic arc ion-plating are now used in addition to the conventional ones such as the radio frequency (rf) plasma assisted chemical vapor deposition (PACVD) and the ion beam deposition. It is required to use these DLCs properly for each usage. Another topic in these days is a flexible DLC film that uses rubber as the substrate material instead of the generally used ones such as metals and ceramics. This new DLC film is applied to the rubber seal ring (O-ring) for zoom lens system of $35 \mathrm{~mm}$ compact cameras.
\end{abstract}

\section{1. は じめに}

最近注目を集める材料に炭素がある。テレビや雑誌で, フラーレンやカーボンナノチューブという言葉を目にさ れることが多いと思う。炭素系材料の歴史は意外に古く, 皆さんが最も身近にお世話になったのが鉛筆の芯だろ う。女性の方なら, 真っ先に思いつくのは, ダイヤモン ドかもしれない。しかし, 約 20 年前から私たちの身の 回りで, この炭素が形を変えていろいろな用途に使われ だしている。この炭素を膜状にして用いられている物の ひとつにDLC（ダイヤモンドライクカーボン）がある。 この膜の用途が, 我々の身の回りで着実に広がっている。 本稿では, この DLC とその実用例, 今後の可能性につ いて述べる。

\section{DLC とは}

最初に DLC を形成したのは, 1970 代のはじめにイオ

E-mail: nakahigashi@nippon-itf.co.jp
ンビーム蒸着法を用いて Aisenberg らが合成されたのが 最初であるといわれている11。その後, Vora らにより, プラズマ分解蒸着法による形成が試みられた ${ }^{21}$ このこ ろ, 炭素系材料は, 摩擦係数が低いことから, 摺動材料 として注目されており, 特にダイヤモンド薄膜の形成に は多くの研究所や企業が精力を注いでいた。DLC は, その際の副産物として形成されたといわれている。当時, DLC はいろいろな名前で呼ばれていた。DLCに名前が 落ち着いたのは, 2000 年ころである。炭素原子から構 成されている材料として, ダイヤモンド, グラファイト, DLC が上げられる。これらの構造を Fig. 1 に示す。炭 素原子は, 四配位の結合を持っており, ダイヤモンドは, ダイヤモンド構造 $\left(\mathrm{sp}^{3}\right)$ から構成される。一方, グラ ファイトは, グラファイト構造 $\left(\mathrm{sp}^{2}\right)$ から構成され, 層状構造を有している。この層状構造は, 皆さんがよく ご存じのフッ素樹脂である PTFE（ポリ・テトラ・フル オロ・エチレン) も同じ構造を有している。しかし, こ のバンド構造は, 大きな面圧がかかると層状に剥離して いくため, ここから発生した摩耗紛が凝着を引き起こす 


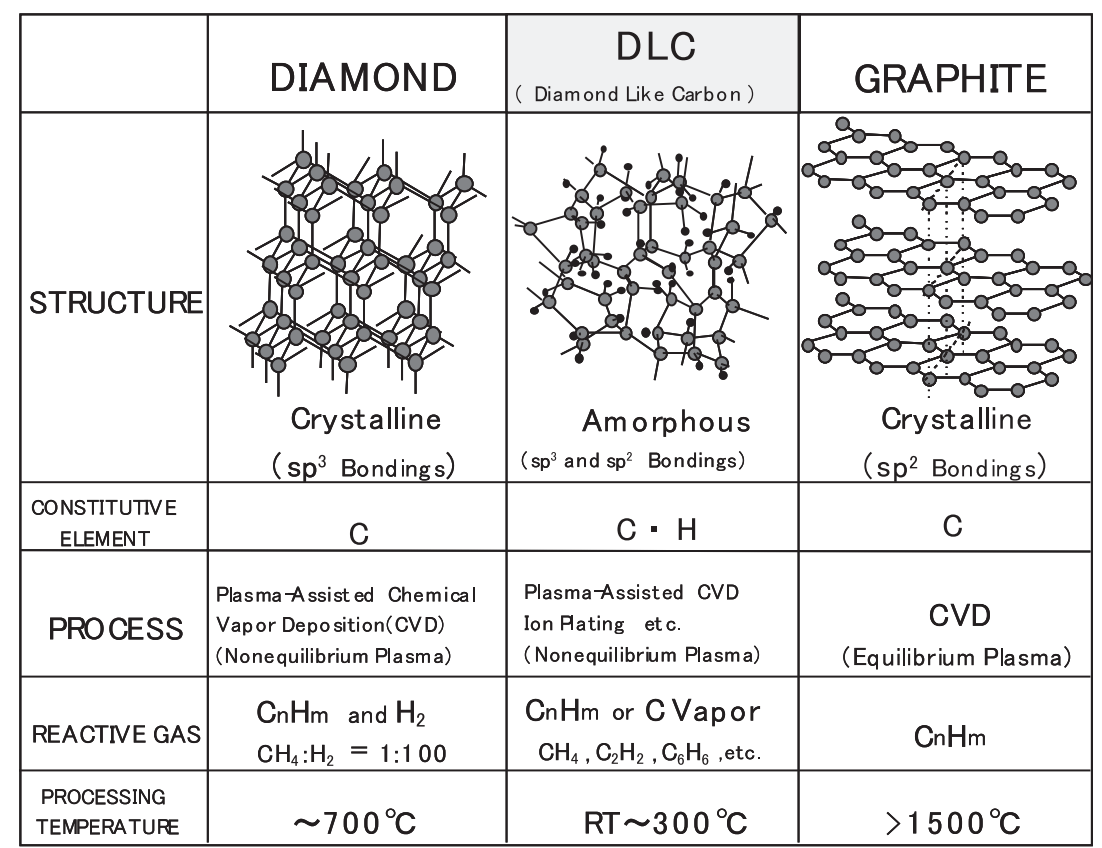

Fig. 1. Comparison of DLC's structures.

ことになる。DLC は，これらのダイヤモンド構造とグ ラファイト構造の両方から構成されており, 部分的には, 水素との結合を含んだアモルファス構造になっている。 このような様々な構造の違いは, 成膜環境に起因してい ると考えられる。すなわち, ダイヤモンドとグラファイ 卜は, 高温下で形成されるが, DLC 膜は, $250^{\circ} \mathrm{C}$ 以下 の比較的低温でしかも真空中で形成される場合が多い。 DLC 膜の性質は, ダイヤモンドとグラファイトの中間 的な性質を持っている。

DLC の摩擦係数は, 膜中の水素量と比例するといわ れている。現在, 生産工程では, 高周波プラズマ法とイ オン化蒸着法が主に用いられている。高周波プラズマ法 は, メタンガスを原料に用い, 容量結合型のプラズマ電 極を用いて成膜が行われる。膜質は, 膜中水素が多いた め, 平滑性に優れ, 摩擦係数も小さいが, 若干硬度が低 い。一方, イオン化蒸着法は, 原料にベンゼンを用い, イオン化した炭化水素を直流で加速するため, 膜中から 水素がたたき出され, 膜が硬くなるが, 若干面粗度が悪 くなる。このため, 高周波プラズマ法は, 摺動用途に向 き, イオン化蒸着法は, 金型や刃物等に用いられている。 しかし, 用途によっては, これらの欠点と思われる点は 大きな問題とはされず, すでに量産工程で用いられてい る製品も少なくない。最近，これらの製法を用いた膜の 高性能化として, 高硬度化・高密着化が求められている。 高硬度化の手法として, アーク法が開発されているが密 着力に乏しい。また, 密着力の改善方法として, DLC 膜中にメタルドープを行うことで, 膜の内部応力を低減
する検討が行われている。

\section{DLC 膜の用途開発}

DLC 膜の特性と用途を Fig. 2 に示す。1980 年代，最 初に実用化されたのは, 携帯型カセットプレーヤーのイ ヤーフォンへの搭載である。これは, DLCが非常に硬 く, 表面弾性波伝達特性が非常によいため, 低周波から 高周波までの音の伝達が可能なことがわかり採用され た。しかし, 材料開発のスピードは速く, すぐに DLC を用いなくてもよい金属積層箔等が開発され，この製品 は大幅に減少した。現在では, 膜厚制御により色合いを 制御できることから, 一部の輸出向けとして生産が行わ れている。その後, 而磨耗性, 低摩擦を目的に, AV 機 器の磁性テープと摺動するシャフト関連に実用化が進ん だが, 1994 年の湯水混合栓までは大きなヒットが見ら れなかった。1980 年代に, シリコングリースを多用す るマーケットとして, 混合栓・医療機器（注射針, 注射 器内ゴム栓) があったが，このシリコングリースに発ガ ン性があるとの報道から, 米国の会社が供給を取りやめ ることになった。医療関連メーカーは, 安全なシリコン グリースを自前で生産し, このピンチを乗り切った。こ れは, グリースがないと注射を受ける患者の苦痛がなく せないことがわかったからである。一方,一部の水洗機 器メーカーは, グリースレスに動き出した。その結果, DLC が採用された混合栓は, グリースレスというエコ ロジーへの注目も手伝い, 現在までに 600 万ユニットが 生産された怪物製品となった ${ }^{3}$ 。この採用が DLC の用 


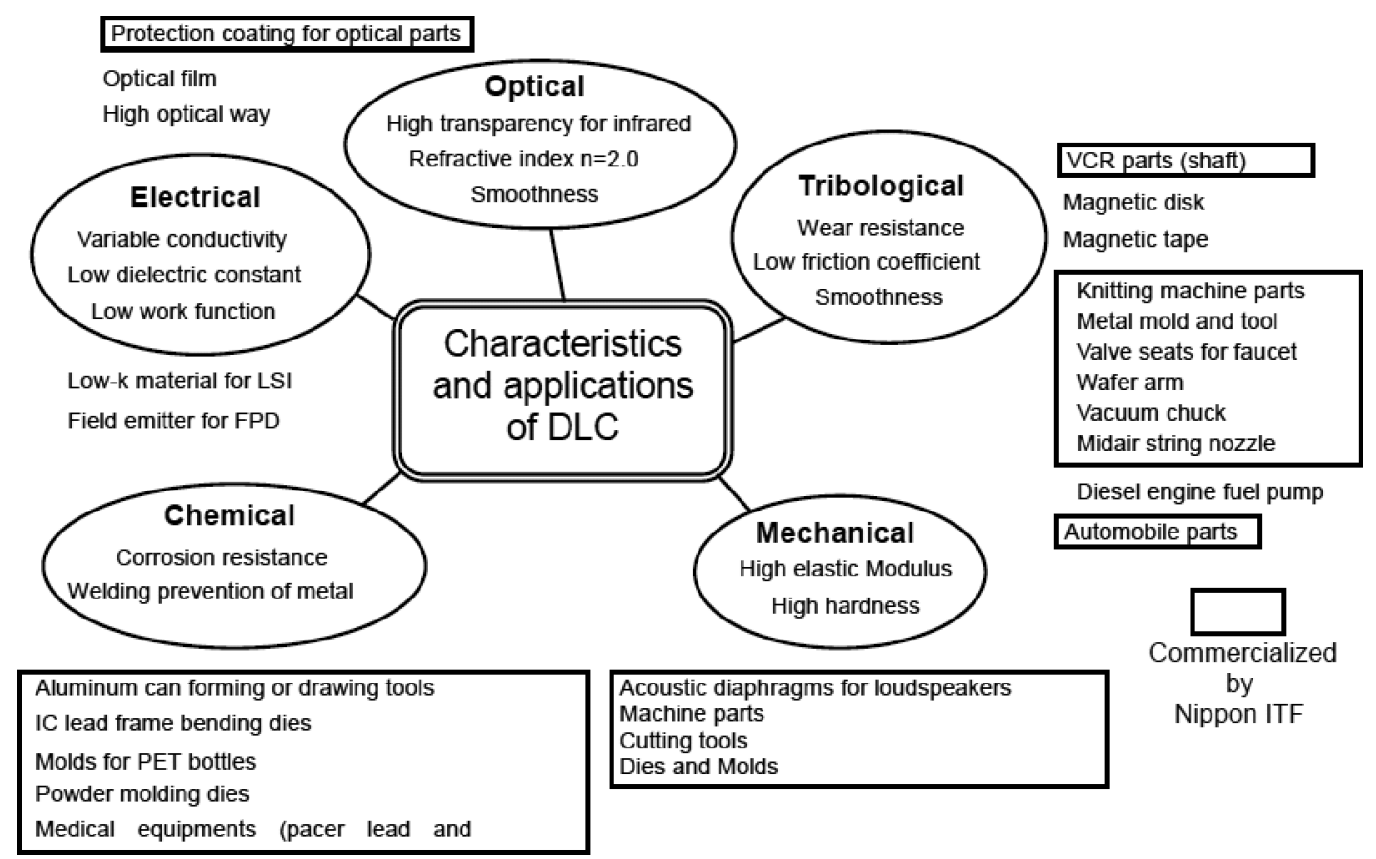

Fig. 2. Characteristics and applications of DLC.

途開拓に火をつけた。最近, このグリースレスという言 葉は, 廃棄物処理法や環境問題も絡夕各界から聞かれる。

これらの特徵から, DLC 膜の応用例は,

・離型性向上を目的に，ICリード曲げ金型，製缶金 型，PET ボトル金型等の金型部品

・滑り性，耐摩耗性向上を目的に，ビデオテープのガ イドシャフト, 回転軸部品, 混合温水栓, ハードディス クの回転盤，磁気ヘッド等の機械部品

- 滑り性, 耐摩耗性, 発塺防止向上を目的に, 搬送レ 一ル，シリコンウェハ搬送用アーム，ガイド等の搬送機 器部品

に用いられていることが知られているが，それ以外の家 電, 飲料, メディカル等の分野でも幅広く用いられだし ている。例えば，プラズマディスプレイパネルの電子放 出電極, バーコードリーダー用硝子への耐磨耗性膜, LSI の層関絶縁膜等である。特に, 従来の金属やセラミック 又等の材料以外に樹脂・ゴム等の高分子基材への適用が 広がっている4。

\section{4. すべるゴム}

DLC は, 硬くもろいため, 硬く変形しにくい材料の みにコートできるとされていたが，ある時，ゴムなどの 変形を伴う基材にコーティングすることが試みられた。 これは, 当時の摺動材料として主流であった PTFE の焼 付け温度が $200^{\circ} \mathrm{C}$ 以上と高く, 耐熱性の低い基材への コートは困難であり, しかも密着性が悪いためよく剥が れたからである。真空装置へ高分子材料を持ち込むのは,
通常アウトガスが出るため不可とされていた。その常識 にとらわれず，低温でコートが可能なプラズマ気相蒸着 装置の中に，耐熱性の高いシリコンゴムを持ち込み，コ ーティングを試みたのが，高分子向け DLC のスタート だった。現在では, 基材温度は 60 度以下で成膜ができ る。シリコンゴム上に形成した膜の表面形態を Fig. 3 に 示す。膜厚が約 $0.01 \mu \mathrm{m}$ の時は, 膜が夕イル状に並んで いるのがわかる。これが，ゴム上で剥がれないメカニズ ムである。厚膜にするとこの割れ目がわからなくなる。 すべるゴムのマーケットがあるのか，実用に耐えうるの か等の実際の適用品での性能調査が始まり, 現在では, 固着防止のパッキン, $35 \mathrm{~mm}$ ズームカメラ用 $\mathrm{O}$ リング 等が数十万個/月で生産されている5)。

\section{PET ボトル入りビール}

塩化ビニルが燃焼すると, ダイオキシンが発生するた め, 使用が禁止され, 身の回りの樹脂容器やフィルムの ほとんどが，ポリエチレンに移行したのはご存じのとお り。特に, 病院で見慣れた注射器, 点滴の容器が樹脂化 している。これは, 硝子容器から発生する硝子破片が, 注射液内に混入する問題からどんどんなくなっている。 また，レトルト食品，スナック菓子の包装も，ポリエチ レン, ポリプロピレン等のリサイクル可能な材料に移行 している。ここで問題は，これらの樹脂は思ったほど酸 素ガス等の遮断性が良くないことである。つまり, 薬品 や食品の寿命が短くなる。そのため, リサイクルもでき てこのガス遮断性を改善する方法の一つとして，DLC 


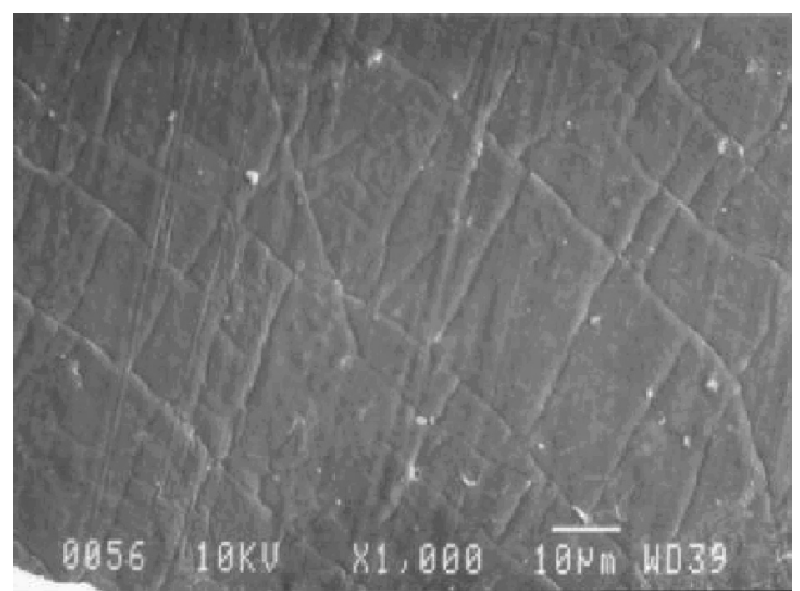

(a)

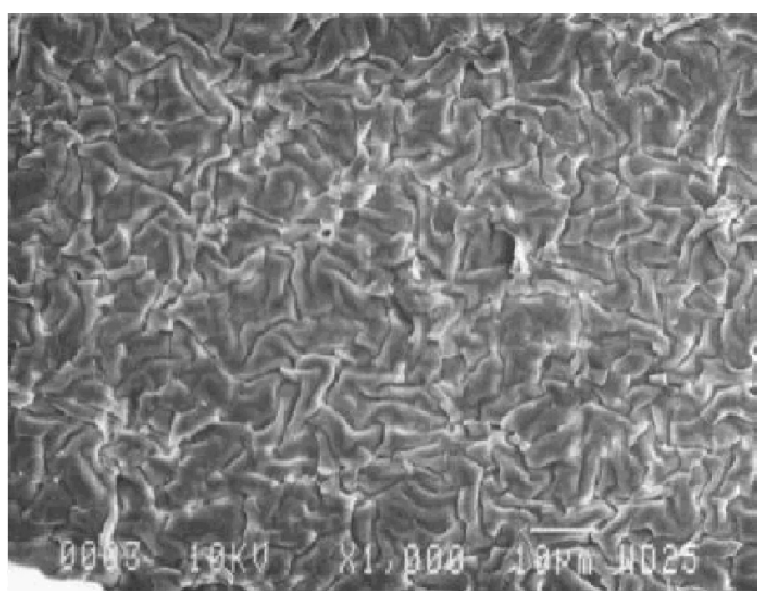

(b)

Fig. 3. Surface morphology of a DLC films determined by scanning electron microscopy: (a) Thickness is $0.01 \mu \mathrm{m}$; (b) $1 \mu \mathrm{m}$.

Thickness of polyethylene seat $\mathrm{t}=30 \mu \mathrm{m}$

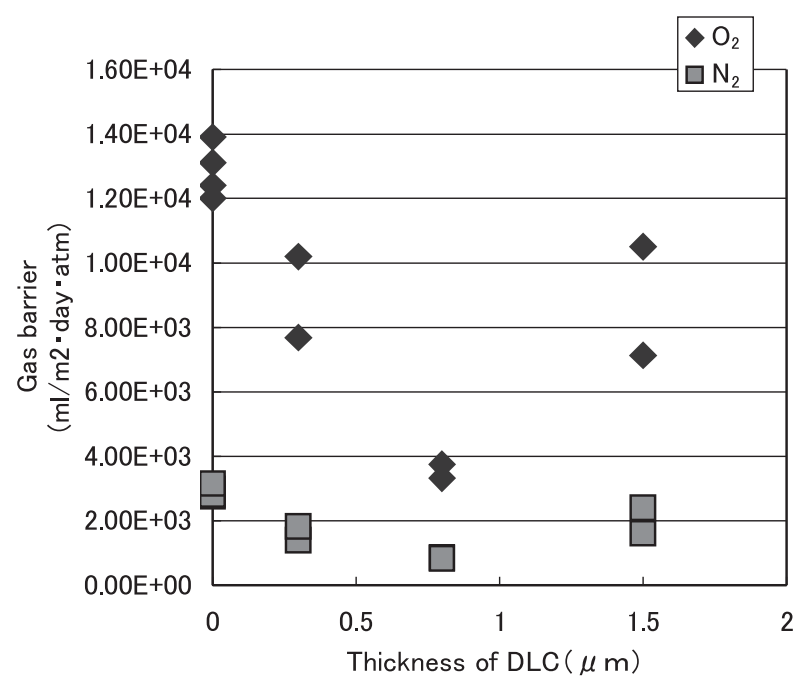

Fig. 4. $\mathrm{O}_{2}$ and the $\mathrm{N}_{2}$ gas barrier of a flexible DLC film that deposited to polyethylene.

が検討されている。酸化ケイ素のコートは, 昔から用い られているが, 真空蒸着法のため, アウトガスの多い樹 脂やゴムにはコートができない, コストが高い等の課題 があった。そこで, DLCがガス遮断膜として使えない かと検討が始まった。特に, 日本はお茶の消費が多く, 緑茶は酸素を嫌がることから, 加熱型の容器内面に DLC コートが採用された6)。Fig. 4 に DLC コートされたポリ エチレンの酸素, 窒素の透過率を示す。酸素の透過率は, $0.8 \mu \mathrm{m}$ の DLC 膜のコートによって $1 / 4$ にまで低下する ことがわかる。この用途は, 樹脂から漏洩する環境ホル モンのバリアとしても注目されている。近い将来, アル ミ午がなくなり, PET 容器入りのビールが大勢を占め
る日も近いと予想される7”。

\section{6. 医療分野への適用}

DLC は，炭素と水素から構成され，生体適合性の良 いことは早くから知られていた。最近, 高分子にコート できる技術や基材変形に対して剥がれにくい膜が開発さ れ, 体内に埋め込む医療器具への応用が注目されている。 埋め込む医療器具は, 金属部品が多く, 重金属の溶け出 し等を防止する検討が進められている。今後, 大きなマ 一ケットに成長すると予想される医療向け材料として, カテーテル等のシリコンエラストマーに DLC をコート したものが注目されている。この材料を用いた血管との 摩擦・磨耗の低減, 抗血栓性を狙った開発 ${ }^{8}$ や人工関節 ${ }^{91}$ への検討が始まっている。

\section{7. ま と}

低摩擦材料として注目される DLC 膜は, 従来高硬度 基材にしかコーティングできないとされていたが, 膜形 態や膜質を制御することで, 基材変形を伴うゴムや樹脂 にもコーティングが可能になった。従来考えられていた 摺動用途以外に，ガスバリア性やメディカル等のいろい ろな用途検討が始まり, 我々の身の回りの製品に使われ だした。環境に優しいコーティング材料として, さらに 用途が広がるものと思われる。

\section{文献}

1) S. Aisenberg and R. Chabot: J. Appl. Phys. 42, 2953 (1971).

2) H. Vora and T.J. Moravia: J. Appl. Phys. 52, 6151 
(1981).

3) 桑山健太 : トライポロジスト 42, 436 (1997).

4) 中東孝浩, 村上泰夫, 竹内 上, 緒方 潔, 浅儀典 生, 今井 修：トライボロジー学会 春季講演会予 稿 (1998) p. 366.

5) 中東孝浩, 井浦重美, 駒村秀幸, 石橋義行 : トライ ボロジー学会 春季講演会予稿 (2002) p. 109.

6) 山下裕二：ニューダイヤモンドフォーラム平成 12 年度第 2 回研究会講演要旨集 (2001) p. 18.
7) 中東孝浩：表面技術 53, 715 (2002).

8) 小島宏司, 島田 厚, 長田博昭：人工臓器 28,541 (1999).

9) Y. Takeichi, T. Nakahigashi, Y. Tanaka, T. Yamane and M. Uemura: Fukuoka International Forum: Biotribology 2003, Proceedings of the 4th International Biotribology Forum and the 24th Biotribology Symposium (2004) p. 33.

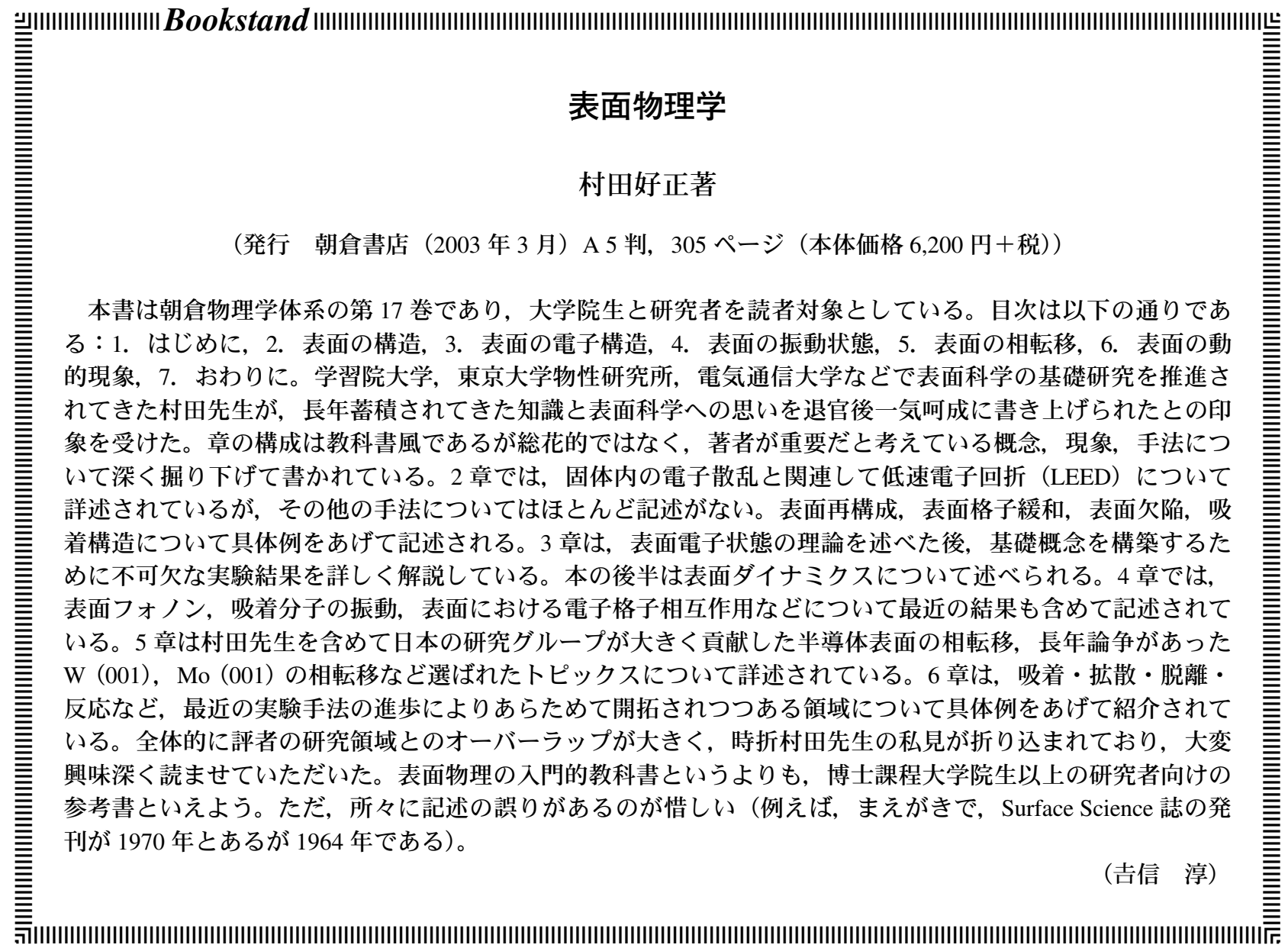

